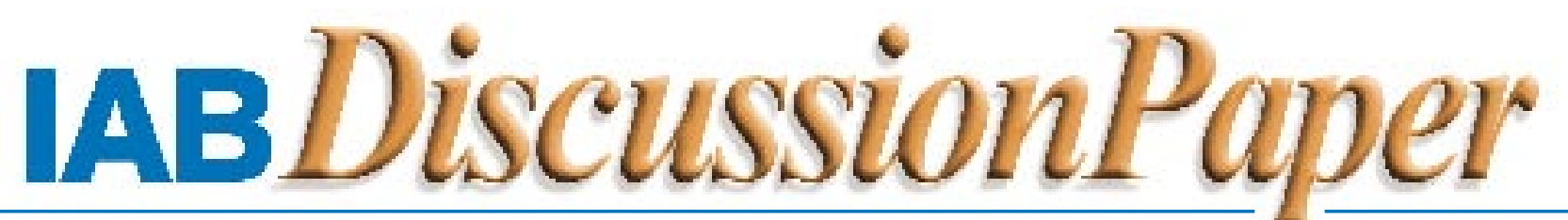

Beiträge zum wissenschaftlichen Dialog aus dem Institut für Arbeitsmarkt- und Berufsforschung

No. $5 / 2007$

\title{
Does unemployment help or hinder becoming independent? \\ The role of employment status for leaving the parental home
}

Marita Jacob, Corinna Kleinert 


\section{Does unemployment help or hinder becoming independent? The role of employment status for leaving the parental home}

Marita Jacob (University of Mannheim), Corinna Kleinert (IAB)

Auch mit seiner neuen Reihe „IAB-Discussion Paper“ will das Forschungsinstitut der Bundesagentur für Arbeit den Dialog mit der externen Wissenschaft intensivieren. Durch die rasche Verbreitung von Forschungsergebnissen über das Internet soll noch vor Drucklegung Kritik angeregt und Qualität gesichert werden.

Also with its new series "IAB Discussion Paper" the research institute of the German Federal Employment Agency wants to intensify dialogue with external science. By the rapid spreading of research results via Internet still before printing criticism shall be stimulated and quality shall be ensured. 


\section{Contents}

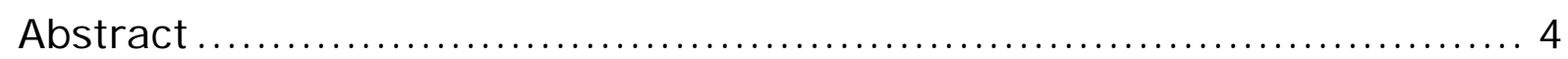

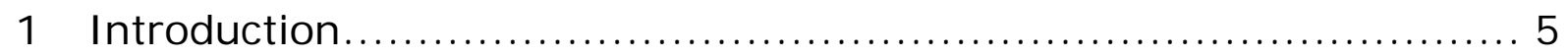

2 (Un)employment and leaving home.................................... 6

3 Theoretical considerations and hypotheses $\ldots \ldots \ldots \ldots \ldots \ldots \ldots \ldots \ldots \ldots$

4 Data, variables and methods ..................................... 13

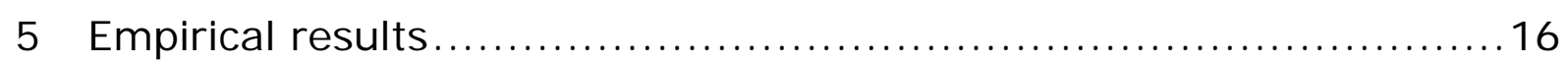

5.1 Own (un-) employment and welfare state benefits $\ldots \ldots \ldots \ldots \ldots \ldots \ldots \ldots 17$

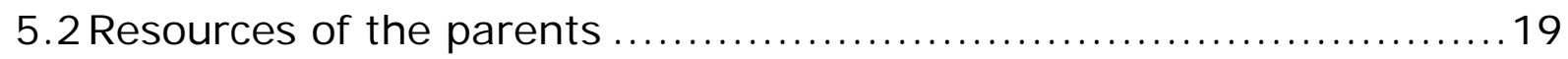

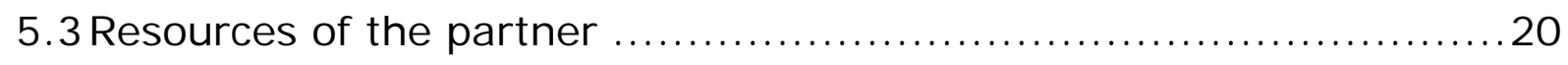

5.4 The impact of partnership status on leaving home.................. 21

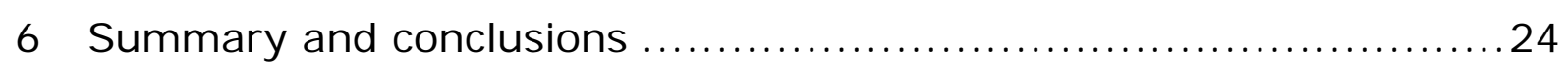

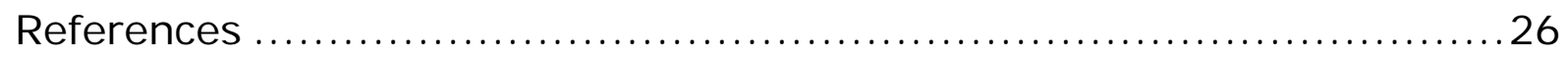

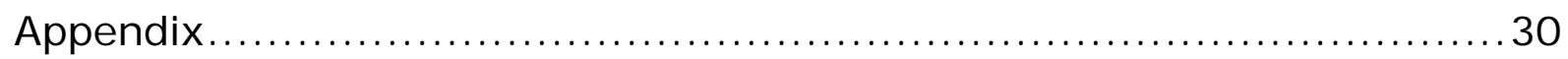




\section{Abstract}

There are two broad trends in industrialised countries motivating this paper: On the one hand, the life phase between youth and adulthood has prolonged and diversified; on the other hand, entering the labour market has become more complex and insecure.

In this paper we combine two aspects of these trends by analysing the effect of unemployment on leaving home. Extending previous research, we use a resource-oriented theoretical framework that allows us to elaborate the impact of employment related resources of different actors. Our main hypothesis is that availability of employment related resources matters for leaving home. Further we assume that several actors are involved in the decision for leaving home: individual, welfare state, parents and partner. Resources of each can be pooled, and resources of other actors can compensate for own shortages.

In the analyses we use life history data of two birth cohorts in West Germany. We find that for young adults with partners own unemployment accelerates leaving home, while for singles leaving home is delayed. Parental unemployment or unemployment compensation benefits also have only an effect if young adults have no partners. Thus, partnership status plays a crucial role in shaping the transitions of youth to residential independence.

Keywords: leaving home, unemployment, partnership, parental resources JEL-Classification: J 12, J64, Z0

We would like to thank Ellen Verbakel (Radboud University Nijmegen), Holger Seibert $(I A B)$, Laura Romeu Gordo (IAB), Wolfgang Ludwig-Mayerhofer (University of Siegen and (AB), an anonymous referee at University of Mannheim, and participants of the 2006 ISA World Congress of Sociology in Durban for their valuable remarks on earlier versions of this paper. All responsibility for the article remains with the authors. 


\section{Introduction}

In many industrialised Western countries we observe prolonged transitions from youth to adulthood and an increasing variation of individual patterns, e.g. in participation in education and training or in the timing of leaving the parental home. Labour market related research has pointed out that in the last decades entering the labour market has diversified and that in particular unemployment between school and work has become more common. In this paper we will combine these two aspects and ask for relations among them: on the one hand, the experience of unemployment in the transition from school to work and on the other hand, the process of becoming independent from one's parents and leaving home.

In previous studies, economic circumstances have been proven to be of crucial importance in young adults' decisions to leave home (Aassve et al. 2002a, 2002b, Nilsson and Strandh 1999, Whittington and Peters 1996). Therefore one might suppose that young unemployed are less likely to leave as they lack the necessary money to form an own household. On the other hand, unemployment might be positively associated with leaving home, as young people move to a more prosperous region to find a job.

However, these arguments neglect two important aspects: First, there are complicated relations between different events in the transition to adulthood, and second, often more than one actor is involved in the decision process of leaving home. Becoming independent from one's parents often consists of several events. For example, cohabiting, entering paid employment and leaving home may occur simultaneously. Besides the temporal coincidence they are often causally related: Cohabiting necessarily implies leaving home (or having left home already), entering the labour market provides the economic independence to live alone, and enrolling in university can be an occasion to look for a flat together with a partner.

If we assume that leaving home requires at least some economic resources, not only the employment status of the individual, but also parental resources, the partner's employment and financial assistance from the welfare state might be important: For example, for someone with an employed partner a phase of unemployment may not effect leaving home if the partner's employment can compensate for the lack of own resources. In this paper we will include the different actors, their resources and their 
impact on leaving home in a resource-oriented approach. This theoretical framework allows us to study the role of unemployment empirically in more detail and to distinguish the ambiguous role of different events in the transition to adulthood more clearly.

In the next section we provide a short review of previous literature on the effects of unemployment and leaving home. After that, we develop a theoretical framework of the decision process of leaving home including different actors and their resources. On that basis we specify several hypotheses on the role of unemployment. Afterwards our data and methods are described. As we need detailed time-related information on individuals, their parents and partners as well as on the timing of events in different life spheres we use retrospective life history data of two West German birth cohorts. Finally, we present our empirical results and discuss them.

\section{2 (Un) employment and leaving home}

A number of studies have examined the influence of employment status on leaving home. The basic hypothesis underlying these analyses is that economic independence is a prerequisite for moving out of the parental home. Hence, paid employment enables adolescents to establish their own households. Vice versa, unemployment of a young person should delay leaving home. However, the empirical results concerning this relationship are mixed:

Several studies analysing the effect of unemployment on living alone use indicators on the macro level as proxies for the individual's situation. For example, Keilmann (1987) relates the raising age of home leavers at the beginning of the 1980ies to economic stagnation, higher risks of unemployment and decreasing social security payments for young adults. Murphy and Wang (1998) and Aassve et al. (2002b) explain delayed home-leaving with the macro-level economic climate in Britain resp. the United States. A similar result is found in Buck and Scott (1993): Raising unemployment rates on the national level delay leaving home, in particular for those leaving for reasons of independence.

Looking at the effect of individual unemployment, several studies find empirical support for the delay hypothesis (Nilsson and Strandh 1999, Whittington and Peters 1996, Jones 1995, Wallace 1987). These results are confirmed by studies analysing returns to the parents' home after leaving: 
Young people with labour market problems are more likely to return home than young people with regular employment (Nilsson and Strandh 1999, daVanzo and Goldscheider 1990). A contrary result is found by Murphy and Sullivan (1986): In their study young unemployed leave home earlier than employed. They explain their finding by increasing tension and stress the young unemployed experience in their families.

In some studies home-leaving patterns for young men and women have been compared. Here, the empirical results are also mixed: Some studies state that men are more connected to parental resources and the family situation, whereas women are more dependent on their own resources (Whittington and Peters 1996, Buck and Scott 1993). Hence, education and labour market careers are more important for women than for men to establish an own household (Nilsson and Strandh 1999, Aassve et al. 2002b, Konietzka and Huinink 2003). Contrary to this, Whittington and Peters (1996) found in their US study that personal financial resources are more important for men than for women. Distinguishing between different paths out of the parents' home it turns out that for men own income is positively associated with leaving home for reasons of marrying (Buck and Scott 1993).

Parents hold a particularly important position in their offspring's decision to leave home. Goldscheider and Goldscheider (1993) show that parents' expectation when their children will leave home proves to be more correct then the children's. Parental support is a key factor for leaving home, in particular for those leaving the parental home to live alone (De Jong Gierveld et al. 1991). However, Goldscheider and Goldscheider (1993) point out that the effect of a greater parental socioeconomic status per se is not clearly defined: Parents have to provide the available financial resources to their children for residential independence, but they may also use these resources to make living at home more convenient for young adults. On the other hand, lack of parental financial resources clearly hinders leaving home (Aassve et al. 2002b).

The impact of welfare state transfers and public support has been studied only rarely. Comparative studies point out that the impact of employment status varies in different countries according to differences in the welfare regimes (Aassve et al. 2002a): In Spain, Germany and in the UK young 
unemployed stay longer at home than employed, whereas in Denmark the unemployed are most likely to leave home. In that study, the effects of income support and allowances are generally rather weak and the authors assume that this is due to the small amount of benefits - with the exception of Denmark providing rather generous benefits to young unemployed. Studying young people from the Isle of Sheppey, Wallace (1987) concludes that receiving unemployment compensation benefits does not compensate for income from regular employment as young unemployed are still less likely to leave home than employed.

Summarising the existing research, it leaves us with two open questions: First, most studies concentrate only on the effects of one or two actors involved in the process of leaving home. Several studies take into account the parents; others concentrate on country differences and on welfare state transfers. In particular, the role of the partner is not analysed in the most of the existing literature. Instead, several studies distinguish between the transition patterns of young women and men and the different impact of their employment status and income. None of them takes into account that these differences could be explained by the partners of young women and men: Having a partner might increase the process of leaving home, and the partner's employment situation may compensate for a lack of own resources. As women often engage at a younger age than men in a stable partnership (with an older, possibly employed partner), the heterogeneous gender patterns of leaving home hence might refer to mating behaviour and union formation.

Second, the overlap of different events is not addressed. In previous research different pathways out of the parental home were often modelled separately (e.g. living alone, cohabiting, leaving for reasons of education and training, leaving for entering paid employment), assuming the processes and the factors of influence are different for these pathways. However, the respective events (e.g. leaving home and entering a job) are sometimes occurring at the same time, so the separation of the pathways is conceptually not clear-cut.

In general, the existing literature often lacks a comprehensive theoretical background in particular with regard to the individual's employment status and the role of parents and partners and their employment status. There- 
fore, in the next paragraph we develop a decision and resource oriented theoretical framework that allows combining these different aspects. Against this background we will be able to elaborate the effects of unemployment on transitions to residential independence in more detail.

\section{Theoretical considerations and hypotheses}

Previous research often suggested that young persons can freely choose the timing of leaving home and the subsequent living arrangement. From this perspective it is simply a matter of preferences: Some adolescents want to live with a partner, others want to live autonomously and independently from their parents, others leave home as they want to enter higher education (Buck and Scott 1993, Aassve et al. 2002a, de Jong Gierveld et al. 1991). However; the differentiation of these different reasons is not clear-cut: Leaving home to enrol in university can be due to the distance that renders such a step necessary or it can be just an opportunity to gain independence and autonomy. The same applies for leaving the parental home to live with a partner: If there is a partner, cohabitation might stem from the same desire of autonomy, privacy and independence from the parents as for those who leave home not having a partner. Thus, it is more plausible in theoretical terms to assume one single preference of young people to live independently of their parents on one end of the scale and to stay with their parents and enjoy living with them on the other.

Other events in the transition to adulthood, like entering higher education or training, finding employment or entering a partnership, are connected to the decision of leaving home in three respects: First, these events may form occasions that evoke a concrete decision process based on the preference existing before. If a young person has a strong preference for leaving, the new partner, enrolling or finding employment might give the reason to realise this preference. ${ }^{1}$ Second, these events may be an endoge-

1 We assume that there always is a feasible alternative to enrol or to find employment that is compatible with staying at home. For example, in the German higher education system for most young people there is at least one institution within acceptable distance to commute. An alternative to finding a job in one's trained occupation elsewhere is to accept a job in another occupational field close to the parental home. Young unemployed in Germany use this strategy more often than being regionally mobile in order to find occupation-specific employment (Seibert 2006). 
nous part of the decision to leave the parental home: Young people try to enrol in a university far away or seek employment elsewhere in order to realise their preference for leaving home. Third, these events may alter or enhance the preference for leaving home. For example, finding a partner intensifies the preference for leaving home because the desire for privacy adds up to the wish to live autonomously from the parents. Thus, the relations between leaving home and other events in young people's life courses are complex, they can happen simultaneously, and their causality is intertwined.

When, how and where young people move after living at their parents' home not only depends on preference and occasions but even more on the feasibility of leaving home and on the prerequisites for realising one's preference. To solve the problem of simultanous events and obscure causality between preference, occasions and realisation we concentrate on the fact that leaving home is not costless. We assume that establishing one's own household is more costly than staying at the parental home. For example, one has to pay rent or mortgage, one needs some goods and furniture; cooking meals or washing have to be done by oneself and/or paid for.

Thus, irrespective of the different events connected to leaving home realising one's preference to move out is a matter of resources. In that sense, we do not have to be concerned if entering employment is an occasion or a means to leave home, but we can see it simply as source of financial independency. The same argument applies to forming a household with a partner as both partners together have to have sufficient resources, no matter how strong their preferences are to cohabit. Thus, in contrast to events, the connected financial resources are necessary prerequisites for leaving home.

Taking this argument serious, one has to enlarge the view beyond young adults themselves choosing freely when and where to move, but include other actors involved in the decision process to leave home. In our case, the most important actors are their parents, a possible partner, and the welfare state. Resources provided by one or several of these actors can compensate for a lack of own assets and thus should increase young adults' chances to leave home. In this sense, not only (un-)employment of 
the young persons themselves is important, but also the employment status of parents and a partner (if existent).

Summing up, our theoretical model can be characterised by the following arguments:

- We assume that a young adult has a certain preference to leave home or to stay. This preference is not stable but may change over time and with other events in other life domains. ${ }^{2}$

- There are some occasions in that life phase fostering a concrete decision, but the realisation of one's preference to leave home at that occasion is dependent on available resources.

- In any case, leaving home for any individual reasons and at whatever occasions is not costless. Regardless if moving out is connected to entering higher education, entering the labour market, or establishing a stable partnership there are always some costs to bear.

- Therefore, the decision process is strongly influenced by the availability of resources to realise one's preference for leaving. Thus the absence of resources, e.g. in the case of individual unemployment, has a delaying impact on leaving home even if there is a strong preference for leaving.

- A lack of own resources can be compensated by resources of other actors. These are the parents, the partner or financial assistance of the welfare state.

This general resource-oriented model allows deriving specific hypotheses on the role of (un-) employment and the different involved actors:

In accordance with previous research, our main hypothesis is based on the assumption that paid employment is a crucial source of income for young people providing the possibility to realise one's preference for leaving home. Therefore we assume that unemployed persons are less likely to leave the parental home than employed persons. The same should be true for other employment states connected with few financial resources, for example schooling or vocational training.

2 The preference itself may be shaped by available (or expected) resources. To keep the model analytically clear, we do not define a relation here, but take the preference as given. 
However, we expect the effect of unemployment to vary with its duration: The longer unemployment lasts the less likely are individuals to leave home because of two reasons: First, resources and savings e.g. from previous employment get scarce and the young person is running short of money. Second, long unemployment duration may be perceived as a sign for insecure future employment prospects and low employment related resources, at least in the short run. The same arguments apply to previous unemployment that also delays residential independence.

Our theoretical model also points out the role of other actors: First, provisions of the welfare state increase own income and thus reduce the costs of leaving home. Therefore, we expect individuals receiving welfare state transfers to be more likely to leave home than those who do not receive any financial support. With regard to unemployment this means if an unemployed young person is receiving unemployment compensation benefits the delaying effect of unemployment should be less pronounced.

Second, parental resources, in particular father's employment, support leaving home. Previous research showed that parents influence the decision of leaving home to a great deal, but they do not necessarily transfer their material resources to a child who wants to leave. Instead, they may also use them to make staying at home more agreeable. Thus, we expect parental resources to have only a weak positive effect. Furthermore, their impact should be stronger for young singles than for young people in a partnership because they have to rely stronger on their parents due to the lack of other support.

Finally, we expect that having a partner accelerates leaving home because the preference of two partners to leave home may be strengthened by a partner to live with. In general, resources of a partner should have a larger effect on leaving home than parental assets. We expect this effect to be strongest if at least one of the partners is employed thus providing the necessary resources to move together. But even when both partners alone do not have enough resources to move out, pooling their resources may be sufficient to do so. Thus, the effect of own unemployment delaying leaving home should be weaker for adolescents in partnerships. 


\section{Data, variables and methods}

Analysing leaving home as a longitudinal process that is influenced by time-varying factors of the individual, a potential partner, the parents and the state, needs a rich data source. A dataset that includes most of the variables we need is the retrospective life course data of the 1964 and 1971 birth cohorts in West Germany. The data is part of the German Life History study at the Max Planck Institute for Human Development and was collected in 1998/99 in cooperation with the Institute of Employment Research. It provides detailed longitudinal information on the individual educational and employment status as well as on parents and partnerships (Hillmert et al. 2004).

For the analyses we use information of 2801 respondents. We decided to start the process of leaving home at the age of 16 years, because before this age living alone in Germany is prevented by legal restrictions (the right to rent a flat is even restricted to age 18). For the cohort born in 1971 the observation time ends either when the respondents have left home or in case of censoring when the interview was conducted. For the cohort born in 1964 we restricted the maximum observation period to age 28 to make the process time in the two cohorts comparable. Using person-period data format our analyses are based on 235547 personmonths.

The event of actually having left home is quite difficult to define (for a detailed discussion cf. Buck and Scott 1993). Leaving home is a continuous process of becoming independent that cannot be reconstructed simply by residentially having left the parents' home. ${ }^{3}$ Therefore, we decided to use the respondents' self evaluations of the date when they have established their first own and independent household. ${ }^{4}$ Figure 1 shows the number of these events in our data set and their age distribution.

3 Buck and Scott (1993: 864) speak of leaving home as a 'murky event' that often cannot be located at a single point in time. For instance, young people are living away from home but coming home every weekend, and may not define themselves as having left home. Other ones move away for a restricted time, e.g. for military service, and return. A third group may have left home, but return again (Young 1989).

4 In 89 percent the date of household formation exactly matches the first independent residential episode. However, we are aware of possible distortions of this retrospective measure: Respondents might memorise this date selectively and interpret their previ- 
Figure 1 Transition into own households (Kaplan-Meier estimation)

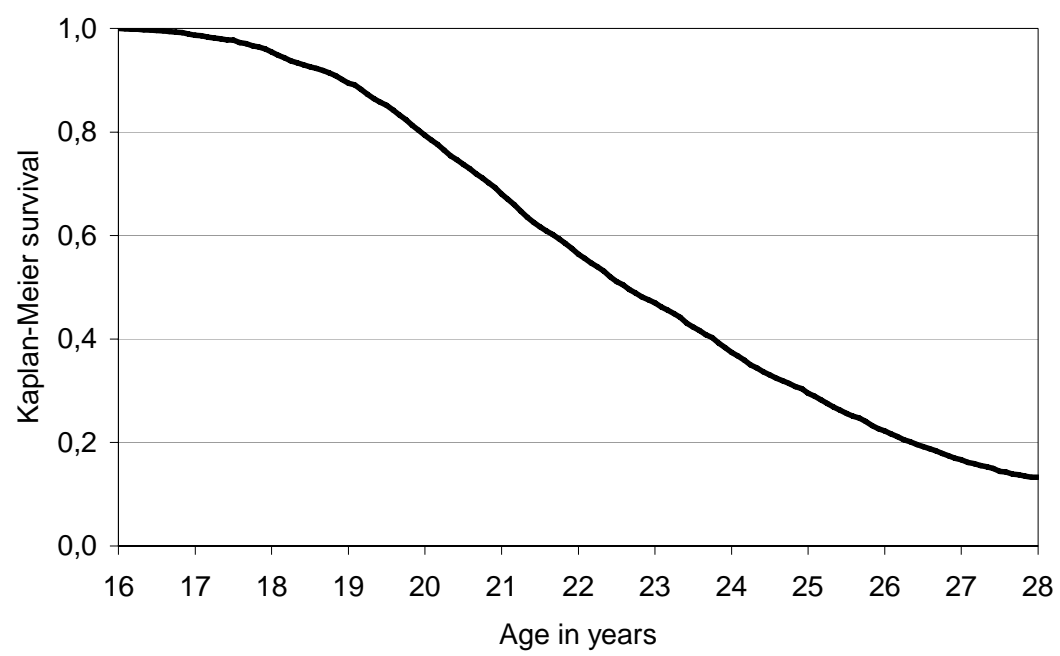

$\mathrm{N}$ (persons) $=2801$

$\mathrm{N}$ (person months) $=235547$

$\mathrm{N}$ (events) $=2381$

Survival time (age in years):

$25 \%=20.42$

$50 \%=22.67$

$75 \%=25.67$

Source: West German Life History Study, birth cohorts 1964/71 (own calculations)

As we already discussed in our theoretical considerations we are not going to distinguish leaving home according to different reasons like living with a partner, education and employment elsewhere as other studies did. Instead we conceptualise individual employment or having a partner as indicators of resources facilitating leaving home and include that information as explanatory variables. Further, we focus strongly on the temporal order of events and the time-dependence of several occasions and resources (cf. Blossfeld and Rohwer 2002: $138 \mathrm{ff}$ ). Therefore we include most information as time-dependent variables into the model. The descriptive characteristics of the variables described below are shown in Table Al in the appendix.

As we are interested in the effects of unemployment, a central factor is individual employment status. We distinguish being in school, training, studying at university, in paid employment, in military or civilian service and other. ${ }^{5}$ To control for the changing impact of resources with varying

ous life in the context of subsequent experiences. Thus, they might tell the interviewers the most salient departure from the parental home. Therefore, we assume 'own household formation' to be a conservative estimate of leaving home.

5 We decided not to lag this information to $t-1$, as we assume that leaving home at month $t$ and entering employment in the same month can be explained by a clear-cut causation: Entering employment provides the resources for leaving home (even if the job was taken for this purpose). Using information on employment status in the previous month probably leads to spurious effects, e.g. if young adults were not employed in the month before leaving home, but changed their status in the same month, this would lead to a positive effect of being not employed. 
duration of unemployment, unemployment is represented by three variables: one to three months, four to ten months, and 11 months and longer. Finally, we include cumulated unemployment experience (in months) previous to actual unemployment to model insecurity of labour market entry more generally.

We restrict the influence of the welfare state on the situation of unemployed (neglecting student grants or other financial support for young people). Receiving unemployment benefits and/or assistance again is included as a time-dependent variable, i.e. we know for each month of unemployment if benefits were received or not.

Regarding parental resources, we control for the employment status of fathers during the adolescence of the respondents. As relatively few young adults in the sample reported their fathers being unemployed, ${ }^{6}$ we added the father's occupational status measured by five categories to capture the material resources of the family. ${ }^{7}$ In the survey data both indicators are only available for the time the respondents were 15 years old. Therefore they are not time-dependent and serve as proxies for the parental resources in the decision process of leaving home.

In the dataset all partnerships lasting longer than three months are included, starting with the date of entering the partnership. ${ }^{8}$ Unfortunately the partner's employment status was only asked for the beginning of the partnership. We use this variable as a proxy for the partner's resources.

Finally, two variables are included in the models to control for further heterogeneity of the sample: cohort membership and sex. However, we will not present separate models for the two birth cohorts or for men and

6 This might be due to selective memory in a retrospective survey. If parents had been unemployed during adolescence respondents will remember that episode (or report it) only when it had been a salient experience with high impact on their own lives when growing up.

7 In case respondents had stepfathers their status is used. Information on mothers' employment and occupational status in adolescence is not available in the data.

8 This information is not lagged to $\mathrm{t}-1$ for the same reasons as described in footnote 9. Furthermore, starting a new partnership and leaving home in the same month is relatively rare (less than 5 percent of all events). In general, having a partner is not necessarily a prerequisite for leaving home: 65 percent of the household formations happened when having a partner, 35 percent when being alone. 25 percent of the persons in the sample had partnerships that ended before founding an own household. 
women. According to our theoretical framework we assume that the effects of our central variables will differ neither for the two cohorts nor for sex when controlling for union status and partner resources. ${ }^{9}$ In contrast, we analyse life phases of young adults with and without partners in separate models as our hypotheses differ according to partnership status in various respects.

The process of household formation starting at age 16 is analysed by estimating event history models. This group of models is adequate if state changes vary over time and right-censored observations occur. For most of the respondents we know if and when they have left home, whereas for those that did not leave home until the end of observation time it is possible that they form a household in the future as well. Event history models take this possibility into account and control not only for state change and censored episodes, but also for the waiting time until the transition occurs or for the time until the last observation takes place. Due to the variety of time-dependent variables in our models, we decided to apply discrete time logit models (for details cf. Yamaguchi 1991). This kind of model is also preferable because we have no theory-driven hypothesis about the age distribution of household formation.

\section{Empirical results}

The results of our analyses are presented as follows: First, effects of own employment status and welfare state benefits are described. Second, the impact of parental resources, and third, the impact of resources of potential partners are presented. These effects are estimated by a joint model for all respondents (Table 1 , Model 1 ). This model is modified in two steps: First, adding interaction terms of own unemployment and parental resources (Table 1, Model 2), and second, adding interaction terms of own unemployment and partner resources (Table 1, Model 3). Finally, the effect of partnership status is analysed by estimating separate models for life phases of young people with and without a partner (Table 2).

9 Contrary to other European countries the age distribution of household formation in Germany did not change systematically in the last decades (Konietzka and Huinink 2003). Although we know from previous analyses that the two cohorts differ in educational participation and in labour market conditions in their early careers (e.g. Hillmert and Jacob 2004), we assume our theoretical mechanisms - the effects of resources on household formation - be the same in the two cohorts. 


\subsection{Own (un-) employment and welfare state benefits}

In the joint model for all respondents (Table 1, Model 1), surprisingly we find no significant effect of actual unemployment on household formation: In tendency, short term unemployed are more likely to leave home than employed young people, and middle and long term unemployed are less likely to leave home. The direction of the unemployment effects thus is consistent with our hypothesis, but none of these effects is significant - a result that partly may be explained by the few unemployment episodes in our sample (see Table A1). We find similar results with regard to unemployment benefits: Again, the direction of the effect supports our hypotheses of helping leaving home, but the effect is not significant. In contrast, previous unemployment experience has a significant impact on leaving home: The longer young adults had been unemployed earlier in their life course the less likely they are to leave home.

In accordance with our resource-oriented theoretical frame non-employment that implies only few own resources (being still at school, in vocational training or being in military service) delays household formation, with the exception of studying in university, which has no significant effect, and the category 'other status', which has a positive effect on leaving home.

Looking at the control variables, we find in correspondence to the existing literature that women are significantly more likely to leave home than men. ${ }^{10}$ Young people born in 1971 stay at home longer than those born in 1964. Finally, the age of young adults is of crucial importance (see Table A2 in the appendix for the age effects in Model 1). The transition rate into own households is very low at the beginning of the process time at age 16, then rises until age 25 and drops again after that peak.

10 Separate models for men and women (not presented in this paper) show no gender differences in household formation, once partnership status and resources are controlled. 
Table 1: Employment status, actors and household formation (discrete time logit, $\exp (\beta)$, robust standard errors)

\begin{tabular}{|c|c|c|c|c|}
\hline & Model 1 & Model 2 & Model 3 & \\
\hline Cohort 1971 & 0.912 * & 0.913 * & $0.912 *$ & * \\
\hline Female & 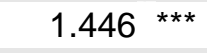 & $1.444 * \star *$ & $1.448 *$ & 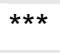 \\
\hline Employed & & Reference group & & \\
\hline In school & $0.289 * \star \star$ & $0.290 * \star \star$ & $0.289 *$ & $\star \star \star$ \\
\hline In training & $0.581 * \star \star$ & $0.582 * * \star$ & $0.581 *$ & $\star \star \star$ \\
\hline In university & 0.913 & 0.913 & 0.913 & \\
\hline In military or civilian service & $0.677 \star \star$ & $0.677 * *$ & $0.677 *$ & $\star \star$ \\
\hline Other status & $1.656 \star \star \star *$ & $1.661 * \star \star$ & $1.657 *$ & $\star \star \star$ \\
\hline 1-3 months unemployed & 1.488 & $1.539^{\dagger}$ & 1.528 & $\dagger$ \\
\hline 4-10 months unemployed & 0.824 & 0.854 & 0.847 & \\
\hline $11+$ months unemployed & 0.578 & 0.680 & 0.542 & $\dagger$ \\
\hline Unemployment benefit & 1.167 & 1.118 & 1.126 & \\
\hline Previous unemployment duration (months) & $0.985 * \star$ & $0.985 * \star$ & 0.985 & $\star \star$ \\
\hline No father & 0.940 & 0.940 & 0.941 & \\
\hline Father employed & & Reference group & & \\
\hline Father unemployed & $1.907 \star \star$ & 1.676 * & 1.907 & ** \\
\hline Father other / no information & 0.991 & 0.996 & 0.991 & \\
\hline Very low occupational status father & 0.905 & 0.907 & 0.907 & \\
\hline Low occupational status father & 0.938 & 0.942 & 0.939 & \\
\hline Medium occupational status father & & Reference group & & \\
\hline High occupational status father & 1.060 & 1.060 & 1.061 & \\
\hline Very high occupational status father & $1.327 * \star \star$ & $1.327 * \star \star$ & 1.328 & $\star \star \star *$ \\
\hline No information on father's status & 1.221 & 1.211 & 1.223 & \\
\hline $11+$ unemployed * father unemployed & & $11.432 * * *$ & & \\
\hline $11+$ unemployed * low status father & & 0.522 & & \\
\hline $\begin{array}{r}\text { No partner } \\
\text { Partner employed }\end{array}$ & $0.368 * \star \star$ & $\begin{array}{c}0.368 * * * \\
\text { Reference group }\end{array}$ & 0.368 & $\star \star \star$ \\
\hline Partner in education / training & $0.768 \star \star \star *$ & $0.766 * \star \star *$ & 0.768 & $\star \star \star ~$ \\
\hline Partner unemployed & $1.402^{\dagger}$ & $1.399^{\dagger}$ & 1.362 & $\dagger$ \\
\hline Partner other / no information & 1.012 & 1.011 & 1.011 & \\
\hline $11+$ unemployed * partner unemployed & & & 17.284 & ** \\
\hline $\mathrm{N}$ & 235547 & 235547 & 235547 & \\
\hline DF & 36 & 38 & 37 & \\
\hline Wald Chi ${ }^{2}$ & 42719 & 42977 & 42732 & \\
\hline
\end{tabular}

Notes:

1. We also control for age by using yearly dummies (see Table A2, Model 1 in appendix).

2. Level of significance: $p:{ }^{\dagger} \leq 0.10 ;{ }^{*} \leq 0.05 ;{ }^{* *} \leq 0.01 ; * * * 0.001$

3. The exponential values of the coefficients (odd ratios, $\exp (\beta)$ ) show by which factor a characteristic raises or lowers the likelihood of a person leaving home compared with the reference category. Values greater than 1 mean an increase in risk, values smaller than 1 mean a risk reduction.

Source: West German Life History Study, birth cohorts 1964/71 (own calculations) 


\subsection{Resources of the parents}

We now turn to the parents. We use father's employment and his occupational status as indictors of resources of the parents (Table 1, Model 1 ). In a second step we include two interaction effects: one of own long-term unemployment and father's unemployment and a second one of own long-term unemployment and (very) low occupational status of the father (Table 1, Model 2). By including these interaction terms we cannot test directly our hypothesis on compensation of own shortages though parental resources, but only the opposite case, the aggravation of the own economic situation in case parents are not able to compensate for it. ${ }^{11}$

First, we find an unexpected effect of father's unemployment. Young adults whose fathers had been unemployed during their adolescence are 1.3 times more likely to leave home than those with employed fathers. This result contradicts our theoretical expectations. Two explanations are possible here, considering that this variable measures father's unemployment at age 15: First, children might leave home early to reduce economic pressure of their parents if their father is unemployed. Second, unemployment of the father might complicate relations between parents and children in their adolescence, and this might be a reason to leave the parental home relatively early.

The effect of father's occupational status follows our resource-oriented hypotheses: The higher the occupational status of the father in their youth, the higher the odds to leave the parental home. This effect is only significant for fathers with a very high occupational status.

Regarding the two interaction terms between own unemployment and father's employment or occupational status, only one has a significant impact on household formation (Table 1, Model 2): If own long-term unemployment is accompanied by unemployment of the father during adolescence, young adults have a far higher chance to leave home than young adults on which only one if these characteristics applies. This finding contradicts our resource-oriented hypotheses, in which we assumed that few resources of both actors, parents and children, should have a cumulative

11 This modelling was chosen due to the reference categories: We use consistent reference groups for own, father's and partner's employment state (always 'employed'). 
negative effect on leaving home. Here, the above mentioned explanation for the positive effect of father's unemployment could play a role as well: Relations between young adults and their parents could be particularly difficult, if both the child and the father are unemployed because in this case both actors spend a lot of time in the common household. In contrast, own long-term unemployment accompanied by a (very) low occupational status of the father does not have a significant effect on leaving home. Thus, if young unemployed have only little parental resources the process of leaving home seems not to be any different than in case of own unemployment with higher parental resources. All in all, our hypothesis on the compensatory function of parental resources is not supported.

\subsection{Resources of the partner}

We expected the partner to be of greater influence for leaving home than the parents or welfare state support. In our theoretical framework we also pointed out that besides simply the existence of a partner his or her resources are influential, because they may compensate for a lack of own resources. In our model, we control for partnership status and for the employment status of the partner at the beginning of the partnership (Table 1, Model 1). To (indirectly) test the compensation function of partner's resources, we include again an interaction effect of own long-term unemployment and having an unemployed partner (Table 1, Model 3).

In accordance with our hypotheses, having no partner delays leaving home. Young adults without a partner are 0.4 times less likely to form an own household than those with an employed partner. If the partner is still in education or training, household formation is delayed as well, but to a lesser degree. In contrast, having an unemployed partner accelerates home leaving compared to having an employed partner. On first sight this result contradicts our hypotheses. However, it may reflect our hypothesis on partner support from the partner's perspective: If the partner is unemployed pooling resources may facilitate the decision to leave the parental home and the (employed) partner supports the unemployed.

The interaction between an own lack of resources and that of the partner can be analysed more detailed by examining the interaction term between own long-term unemployment and partner's unemployment (Table 1, Model 3). Contrary to our theoretical expectations and similar to the inter- 
action of father's and own unemployment this interaction term shows a significant and high positive effect: Couples where both partners are unemployed are far more likely to leave home than couples in which only one partner is unemployed. This result is difficult to explain, foremost, because we do not know the exact timing of the partner's unemployment episode in relation to own unemployment. In general, young couples, in which both partners are unemployed, seem to be a group for which household formation follows distinct patterns not comparable with other couple constellations.

Including this interaction effect and thus controlling explicitly for this distinct subgroup of young people, short-term and long-term unemployment (of the other groups) suddenly show significant effects: While at the beginning of unemployment episodes it is more likely to leave home than when being employed, long unemployment duration has a reverse effect and hinders household formation.

To resume, our hypotheses on the impact of partner's resources are partly supported by the empirical analysis: Not having a partner clearly delays leaving home. The same can be found for young adults with partners still in education or training. In contrast, unemployment of the partner and unemployment of both partners seem to accelerate leaving home.

\subsection{The impact of partnership status on leaving home}

In a second step, we examine if the impact of own and parental resources differs for individuals in life phases with and without a partner to test our hypothesis on the greater influence of parental support for young singles. We estimate the effect of own status and family resources separately for these two groups (Table 2).

Considering first the effects of own unemployment for those without a partner the coefficients of the three central variables (short-, middle- and long-term unemployment) are all smaller than 1 . However, only the effects of short-term and long-term unemployment are significant. Thus, unemployment delays household formation for singles, irrespective of its duration. Receiving unemployment benefits helps leaving home for those without a partner. Individuals that receive unemployment benefits are three times more likely to leave home than unemployed individuals not 
receiving benefits. Finally, previous unemployment shows non-significant negative effect on leaving home for singles.

Table 2: Household formation for life phases with and without partner (discrete-time logit model, $\exp (\beta)$, robust standard errors)

\begin{tabular}{|c|c|c|}
\hline & Without partner & With partner \\
\hline Cohort 71 & 1.090 & $0.811 * \star \star$ \\
\hline Female & 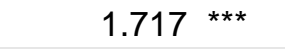 & 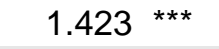 \\
\hline Employed & \multicolumn{2}{|c|}{ Reference group } \\
\hline In school & $0.315 * * *$ & $0.264 * \star \star$ \\
\hline In training & $0.739 \star \star$ & $0.494 * * *$ \\
\hline In university & $1.592 * \star \star$ & $0.614 * * \star$ \\
\hline In military or civilian service & 0.820 & $0.590 * *$ \\
\hline Other status & $1.832 * \star *$ & $1.528 * \star \star$ \\
\hline 1-3 months unemployed & $0.309^{\dagger}$ & $2.566 *$ \\
\hline 4-10 months unemployed & 0.290 & 1.148 \\
\hline $11+$ months unemployed & 0.142 ** & 1.053 \\
\hline Unemployment benefit & $3.723^{\dagger}$ & 0.814 \\
\hline Previous unemployment duration & 0.986 & $0.988^{\dagger}$ \\
\hline No father & 0.853 & 0.960 \\
\hline Father employed & \multicolumn{2}{|c|}{ Reference group } \\
\hline Father unemployed & $1.996^{\dagger}$ & 1.520 \\
\hline Father other / no information & 1.273 & 0.868 \\
\hline Very low occupational status father & 0.897 & 0.904 \\
\hline Low occupational status father & 0.984 & 0.929 \\
\hline Medium occupational status father & \multicolumn{2}{|c|}{ Reference group } \\
\hline High occupational status father & $1.386 * \star *$ & 0.883 \\
\hline $\begin{array}{r}\text { Very high occupational status fa- } \\
\text { ther }\end{array}$ & $1.812 * \star *$ & 1.042 \\
\hline No information on father's status & 1.156 & 1.308 \\
\hline $\mathrm{N}$ & 154824 & 80723 \\
\hline DF & 32 & 32 \\
\hline Wald Chi ${ }^{2}$ & 19000 & 20763 \\
\hline
\end{tabular}

Notes:

1. We also control for age by using yearly dummies (coefficients not shown in the table).

2. Level of significance: $\mathrm{p}:{ }^{\dagger} \leq 0.10 ;{ }^{*} \leq 0.05 ;{ }^{* \star} \leq 0.01 ;{ }^{* \star \star} \leq 0.001$.

3. The exponential values of the coefficients (odd ratios, $\exp (\beta)$ ) show by which factor a characteristic raises or lowers the likelihood of a person leaving home compared with the reference category.

Values greater than 1 mean an increase in risk, values smaller than 1 mean a risk reduction.

Source: West German Life History Study, birth cohorts 1964/71 (own calculations)

We get a different picture for young adults in partnerships: In this group being short-term unemployed leads to a significantly higher probability of leaving home, while middle- and long-term unemployment has no significant effect. In other words, young adults with a partner who are shortterm unemployed are more likely to build a household than those who are 
employed. For young adults in partnerships receiving unemployment benefits has no significant effect on leaving home. In contrast to young singles, previous unemployment significantly slows down leaving home.

Not only own unemployment, but own employment status altogether shows partly different effects in the two groups: For young adults in partnerships, not only pupils and youth in vocational training are less likely to leave home than employed persons, but also students and men in military or civilian service. The effect of studying in university reverses in both groups: Students without a partner are more likely to leave home than employed individuals, whereas students with a partner are less likely to leave home. Thus, single students seem to be more mobile than students in stable partnerships.

Comparing the cohort effect in the two groups, there is also an important difference: The effect of later household formation in the younger cohort occurs only for couples, whereas singles in both cohorts leave home at a comparable age. Thus, the transition to residential independence per se did not elongate in Germany when comparing these two cohorts. In contrast, partnerships and formations of a joint household seem to have taken place later in the life course. Finally, the difference between men and women decreases once there is a partner but still women are more likely to leave home than men.

Not only the impact of individual resources and characteristics differ for young singles and couples, but also the impact of parental resources: For young adults without a partner father's unemployment has a (weak) significant positive effect on leaving home. We also observe a positive effect for young adults with a partner but it is not significant. The same holds for the father's occupational status: A strong positive effect can be found for young adults without partner, i.e. the higher the father's occupational status the more likely young singles leave home. But the effects disappear for individuals with partner. These results show that parental resources seem to be far more important for young singles than for young couples regarding household formation. 


\section{Summary and conclusions}

In this paper we have analysed leaving home and household formation applying a resource- and actor-oriented theoretical background. Within this frame the impact of unemployment was of particular interest - here perceived as a lack of resources. We discussed different forms of compensation for lacking own resources that can be provided by other actors involved in the process of leaving home, by well-off parents, an (employed) partner or by welfare state transfers. Defining leaving home solely as a matter of preferences and available resources we did not need to distinguish different reasons for moving out like leaving home to enter higher education, to cohabit or to live alone that often have been analysed separately in the previous literature. We consider this distinction as misleading as (1) these events may occur at the same time, e.g. enrolling at university and moving together with a partner, and because (2) according to our theory the decision process with regard to resources follows the same mechanisms and processes irrespective of the subsequent living arrangement. This consideration led us to another major point of our argument: Modelling leaving home needs a strictly time-related and life course perspective. However, we still can not grasp expectations (that may influence current behaviour), but by using a strict time scale on the order and sequence of events we can follow our central argument that some resources have to be available before leaving home and building one's own household is possible.

The first hypothesis on the importance of individual employment related resources to leave home is only partly supported by our findings. Those young people who are currently in a situation of few own resources (like being at school, in vocational training or studying or being in military service) are more likely to stay at home than employed individuals. In contrast, the expected delaying impact of unemplyoment varies with its duration. In the first three months of unemployment household formation is even accelerated. However, the longer unemployment lasts, the less likely young people move out of the parental home. Previous unemployment experience also delays leaving home significantly. This supports our hypothesis on decreasing availability of resources: The longer current unemployment lasts and/or the longer previous unemployment experience had been, the more resources (like savings) have already been spent, e.g. on 
daily consumer behaviour, and employment related resources in the near future are insecure.

One of our main empirical results regarding the actors involved in the decision process of leaving home is the impact of a partner. Having a partner or not is a crucial determinant for household formation. First, young adults being in a stable partnership are more likely to leave home than young singles. However, a positive partner effect on household formation occurs for both, for employed partners compared to partners in education or training, but also for unemployed partners. Second, individual unemployment has a different influence if there is a partner or not. We find an accelerating effect of unemployment on household formation in the group with a partner, whereas young unemployed without a partner are less likely to leave home than employed, regardless of unemployment duration. These results support our hypothesis that partners support each other in case of need and resources of both individuals are pooled. Unemployment benefits matter only for singles significantly and accelerate leaving home. Thus, welfare state transfers are actively used only by young unemployed singles that are probably more mobile, e.g. to search for another job at another place.

The importance of partner status is also visible if we look at parental resources. From our own previous research we know that educational decisions and labour market entry of young adults are strongly influenced by parental resources (J acob 2005, Dietrich and Kleinert 2006). However, in the case of household formation we do not find a great impact of the parents. Rather, parental influence on leaving home is mediated by the existence and the employment status of a partner. Resources of the parents are more important in the group without a partner, whereas they play hardly a role regarding leaving home in the group with a partner. Thus, individual experiences in another life domain on which the parents have less direct (or indirect) influence reduce the impact of parental resources.

Summing up the results of our paper we extended previous research in the following respects: We showed the importance of modelling leaving home as one single decision in a time-related perspective in two respects: first, for comprehensive theoretical reasoning and second, for the empirical investigation not to distort the (temporal) order of events and the in- 
terdependent, parallel processes in different life domains. Distinguishing between different reasons for leaving home or between different living arrangements conceals part of the impact of partnerships for the decision process of leaving home. Our results show that it makes a huge difference for leaving home in any respect and the impact of different factors on that event if young people are in a stable partnership or not.

However, further research is necessary to fully understand the processes and mechanisms that relate partnership and household formation. In particular our central hypotheses on compensation of resources appears to be much more complicated in the case of couples in the sense that one partner supports the other or that pooling resources 'compensates' for insufficient individual assets. Further complicating is the fact that young couples have not only one pair of parents (the situation from an individual viewpoint analysed here), but two pairs with an individual set of resources the young couple can or cannot rely on. To grasp the complexity of the situation of young couples, future research probably has to change its perspective from an individual to a network related viewpoint.

Apart from partnership status, further analyses will also be fruitful to examine the role of resources of the different actors in younger cohorts. In the birth cohorts analysed here unemployment episodes of the parents were 'rare events', and in the respecting period of time they were cushioned in most cases by relatively high unemployment compensation benefits. Today, especially in the Eastern part of Germany low parental resources and long unemployment episodes of young adults as well as their parents occur more often and are not always compensated by high state transfers. It would be interesting to test our hypotheses on parental and partner support on leaving home in this changed historical situation.

\section{References}

Aassve, Arnstein; Billari, Francesco C.; Mazzuco, Stefano; Onagro, Fausta (2002a): Leaving Home: A Comparative Analysis of ECHP Data. In: Journal of European Social Policy 12: p. 259-275.

Aassve, Arnstein; Burgess, Simon; Chesher, Andrew; Propper, Carol (2002b): Transitions from Home to Marriage of Young Americans. In: Journal of Applied Econometrics 17: p. 1-23. 
Alders, M.P.C.; Manting, Dorien (1999): Household Scenarios for the European Union. Joint ECE-EUROSTAT Work Session on Demographic Projections. Working Paper No. 7. Perugia, Italy.

Blossfeld, Hans-Peter; Rohwer, Götz (2002): Techniques of Event History Modeling. New Approaches to Causal Analysis. Second Edition. Hillsdale, $\mathrm{NJ}$ : Erlbaum.

Buck, Nicholas; Scott, Jacqueline (1993): She's Leaving Home: But Why? An Analysis of Young People Leaving the Parental Home. In: J ournal of Marriage and the Family 55: p. 863-874.

Corjin, Martine; Manting, Dorien (2000): The Choice of Living Arrangement after Leaving the Parental Home. In: de Beer, Joop; Deven, Fred (Eds.). Diversity in Family Formation. Dordrecht: Kluwer Academic Publishers, p. 33-58.

Da Vanzo, Julie; Goldscheider, Frances K. (1990): Coming Home Again: Returns to the Parental Home of Young Adults. In: Population Studies 44: p. 241-255.

DeJ ong Gierveld, Jenny; Liefbroer, Aart C.; Beekink, Erik (1991): The Effects of Parental Resources on Patterns of Leaving Home among Young Adults in the Netherlands. In: European Social Review 7: p. 55-71.

Dietrich, Hans; Kleinert, Corinna (2006): Der lange Arm der sozialen Herkunft. Bildungsentscheidungen arbeitsloser J ugendlicher [The Long Arm of Social Background. Educational Decisions of Unemployed Youth]. In: Tully, Claus (Ed.). Lernen in flexibilisierten Welten. Wie sich das Lernen der Jugend verändert. Weinheim: Juventa, p. 111-130.

Galland, Olivier (1997): Leaving Home and Family Relations in France. In: Journal of Family Issues 18: p. 645-670.

Goldscheider, Frances; Goldscheider Calvin (1993): Whose Nest? A Twogeneration View of Leaving Home during the 1980s. In: J ournal of Marriage and Family 55: p. 851-862.

Haurin, D.R., Henderhott P.H., Kim, D. (1993): The Impact or Real Rents and Wages on Household Formation. Review of Economics and Statistics 75: p. 284-293.

Hillmert, Steffen; Künster, Ralf; Spengemann, Petra; Mayer, Karl Ulrich (2004): Projekt ,Ausbildungs- und Berufsverläufe der Geburtskohorten 1964 und 1971 in Westdeutschland'. Dokumentationshandbuch. [Documentation of the Study ,Education, Training and Early Labour Market Careers of the Birth Cohorts 1964 and 1971' in West Germany]. Berlin: Max-Planck-Institute for Human Development.

Hillmert, Steffen; Jacob, Marita (2004): Multiple Episodes in a Learning Society. Globalife Working Paper 64. Bamberg: University of Bamberg. 
Jacob, Marita (2005): Do Good Jobs Come to Those Who Wait? Unemployment Duration and Subsequent Employment Stability. Paper presented at the Meeting of the ISA Research Committee 28, August 2005, UCLA Los Angeles.

Jones, Gill (1995): Leaving Home. Buckingham, U.K.: Open University Press.

Keilmann, K. (1987): Recent Trends in Family and Household Composition in Europe. In: European J ournal of Population 3: p. 291-325.

Konietzka, Dirk; Huinink, J ohannes (2003): Die De-Standardisierung einer Statuspassage? [De-Standardization of a Status Passage?]. In: Soziale Welt 54: p. 285-312.

Leridon, Henri; Villenueve-Gokalp, Catherine (1989): The New Couples: Number, Characteristics and Attitudes. In: Population: An English Selection 44: p. 203-235.

Moffit, R. (1992): Incentive Effects of the U.S. Welfare System: A Review. Journal of Economic Literature 30: 1-61.

Mulder, Clara H.; Manting, Dorien (1994): Strategies of Nest Leavers: 'Settling down' versus Flexibility. In: European Sociological Review 18: p. 671-689.

Murphy, Mike; Wang, Duolao (1998): Family and Sociodemographic Influences on Patterns of Leaving Home in Postwar Britain. In: Demography 35: p. 293-305.

Murphy, Mike; Sullivan, Oriel (1986): Unemployment, Housing and Household Structure among Young Adults. In: J ournal of Social Policy 15: p. 205-22.

Nilsson, Karina; Strandh, Mattias (1999): Nest Leaving in Sweden: The Importance of Early Educational and Labour Market Careers. In: J ournal of Marriage and Family 61: p. 1068-1079.

Seibert, Holger (2006, forthcoming): Frühe Flexibilisierung [Early Flexibility]. IAB Discussion Paper. Nuernberg: Institut fuer Arbeitsmarkt- und Berufsforschung.

Thornton, Arland; Young-DeMarco, Linda; Goldscheider, Frances (1993): Leaving the Parental Nest: The Experience of a Young White Cohort in the 1980s. In: Journal of Marriage and Family 55: p. 216-229.

Wallace, Claire (1987): For Richer, for Poorer. Growing up in and out of Work. London: Travistock Publications.

Whittington, Leslie A.; Peters, H. Elizabeth (1996): Economic Incentives for Financial and Residential Independence. In: Demography 33: p. 8297. 
Yamaguchi, Kazuo (1991): Event History Analysis. Newbury Park: Sage.

Young, Christabel M. (1989): The Effect of Children Returning Home on the Precision of the Timing of the Leaving-Home Stage. In: Grebenik, Eugene; Höhn, Charlotte; Mackensen, Rainer (Eds.). Later Phases of the Family Cycle Demographic Aspects, Oxford: Clarendon Press, p. 164182. 


\section{Appendix}

Table A1: Variables in the models

\begin{tabular}{|c|c|c|c|c|c|}
\hline Variable & $\mathbf{N}$ & Min & $\operatorname{Max}$ & Mean & St.dev. \\
\hline Age 16 & 235547 & 0 & 1 & .142 & .349 \\
\hline 17 & 235547 & 0 & 1 & .140 & .347 \\
\hline 18 & 235547 & 0 & 1 & .133 & .340 \\
\hline 19 & 235547 & 0 & 1 & .123 & .328 \\
\hline 20 & 235547 & 0 & 1 & .107 & .309 \\
\hline 21 & 235547 & 0 & 1 & .091 & .287 \\
\hline 22 & 235547 & 0 & 1 & .075 & .264 \\
\hline 23 & 235547 & 0 & 1 & .062 & .241 \\
\hline 24 & 235547 & 0 & 1 & .049 & .216 \\
\hline 25 & 235547 & 0 & 1 & .038 & .192 \\
\hline 26 & 235547 & 0 & 1 & .028 & .164 \\
\hline 27 & 235547 & 0 & 1 & .013 & .111 \\
\hline Cohort 1971 & 235547 & 0 & 1 & .509 & .500 \\
\hline Female & 235547 & 0 & 1 & .410 & .492 \\
\hline Employed & 235547 & 0 & 1 & .313 & .464 \\
\hline In school & 235547 & 0 & 1 & .243 & .429 \\
\hline In training & 235547 & 0 & 1 & .301 & .459 \\
\hline In university & 235547 & 0 & 1 & .062 & .240 \\
\hline In military or civilian service & 235547 & 0 & 1 & .037 & .189 \\
\hline Other status & 235547 & 0 & 1 & .026 & .159 \\
\hline 1-3 months unemployed & 235547 & 0 & 1 & .006 & .077 \\
\hline 4-10 months unemployed & 235547 & 0 & 1 & .007 & .082 \\
\hline $11+$ months unemployed & 235547 & 0 & 1 & .006 & .077 \\
\hline Unemployment benefit & 235547 & 0 & 1 & .012 & .107 \\
\hline Previous unemployment duration (months) & 235547 & 0 & 118 & .612 & 3.517 \\
\hline No father & 235547 & 0 & 1 & .026 & .160 \\
\hline Father employed & 235547 & 0 & 1 & .931 & .254 \\
\hline Father unemployed & 235547 & 0 & 1 & .005 & .068 \\
\hline Father other / no information & 235547 & 0 & 1 & .038 & .191 \\
\hline Father very low occupational status & 235547 & 0 & 1 & .133 & .340 \\
\hline Father low occupational status & 235547 & 0 & 1 & .223 & .416 \\
\hline Father medium occupational status & 235547 & 0 & 1 & .301 & .458 \\
\hline Father high occupational status & 235547 & 0 & 1 & .192 & .394 \\
\hline Father very high occupational status & 235547 & 0 & 1 & .087 & .281 \\
\hline No information on father's status & 235547 & 0 & 1 & .038 & .190 \\
\hline No partner & 235547 & 0 & 1 & .657 & .475 \\
\hline Partner employed & 235547 & 0 & 1 & .132 & .338 \\
\hline Partner in education / training & 235547 & 0 & 1 & .193 & .395 \\
\hline Partner unemployed & 235547 & 0 & 1 & .005 & .069 \\
\hline Partner other / no information & 235547 & 0 & 1 & .013 & .115 \\
\hline
\end{tabular}

Source: West German Life History Study, birth cohorts 1964/71 (own calculations) 
Table A2: Age effects on household formation (discrete time logit, $\exp (\beta)$, robust standard errors)

\begin{tabular}{|c|c|c|c|c|c|c|}
\hline \multirow[b]{2}{*}{ Age 16} & \multicolumn{2}{|c|}{$\begin{array}{l}\text { Total population } \\
\text { (Table 1, Model 1) }\end{array}$} & \multicolumn{4}{|c|}{$\begin{array}{c}\text { Wlo partner With partner } \\
\text { (Table 2) }\end{array}$} \\
\hline & .004 & $\star \star \star *$ & .001 & $\star \star \star *$ & .007 & $\star * *$ \\
\hline 17 & .009 & $* * *$ & .002 & $\star \star \star *$ & .009 & $\star * *$ \\
\hline 18 & .015 & $\star \star \star *$ & .003 & $\star \star \star \star$ & .017 & 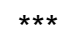 \\
\hline 19 & .021 & $\star \star \star *$ & .005 & $\star \star \star \star$ & .023 & $\star \star \star *$ \\
\hline 20 & .023 & $\star \star \star *$ & .007 & $\star \star \star *$ & .022 & $\star * \star$ \\
\hline 21 & .027 & $\star \star * *$ & .006 & $\star \star \star *$ & .030 & $\star * \star$ \\
\hline 22 & .026 & $\star \star \star *$ & .007 & $\star \star \star *$ & .026 & $\star * *$ \\
\hline 23 & .027 & $\star \star \star *$ & .007 & $\star \star \star \star$ & .029 & $\star \star \star *$ \\
\hline 24 & .030 & $\star \star * *$ & .007 & $\star \star \star *$ & .033 & $\star \star \star *$ \\
\hline 25 & .038 & $\star \star *$ & .010 & $\star \star \star$ & .042 & $\star \star \star *$ \\
\hline 26 & .038 & $\star \star \star *$ & .010 & $\star \star \star$ & .040 & $\star \star \star ~$ \\
\hline 27 & .034 & $\star \star \star$ & .007 & $\star \star \star$ & .042 & $\star \star \star$ \\
\hline
\end{tabular}

Level of significance: $\mathrm{p}:{ }^{* * *} \leq 0.001$

Source: West German Life History Study, birth cohorts 1964/71 (own calculations) 


\section{Recently published}

No.

\section{Author(s)}

1/2004 Bauer, T. K.

Bender, $\mathrm{S}$.

Bonin, $\mathrm{H}$.

2/2004 Achatz, J.

Gartner, $\mathrm{H}$.

Glück, T.

3/2004 Andrews, M. Schank, T. Upward, R.

4/2004 Brixy, U. Kohaut, S. Schnabel, C.

5/2004 Kölling, A. Rässler, S.

6/2004 Stephan, G. Gerlach, K.

7/2004 Gartner, H. Stephan, G.

$\underline{1 / 2005}$ Blien, U. Suedekum, J.

2/2005 Brixy, U. Kohaut, S. Schnabel, C.

$\underline{3 / 2005}$ Lechner, M. Miquel, R. Wunsch, C.

4/2005 Hinz, T. Gartner, H.

5/2005 Gartner, H. Rässler, S.

6/2005 Alda, $\mathrm{H}$. Bender, S. Gartner, $\mathrm{H}$.

$\underline{7 / 2005}$ Haas, A. Rothe, $\mathrm{T}$.
Title

Date

Dismissal protection and worker flows in small establish-

$7 / 04$

ments

published in: Economica

Bonus oder Bias? : Mechanismen geschlechtsspezifischer

$7 / 04$

Entlohnung

published in: Kölner Zeitschrift für Soziologie und Sozialpsychologie 57 (2005), S. 466-493 (revised)

Practical estimation methods for linked employer-employee data

Do newly founded firms pay lower wages? First evidence from Germany

published in: Small Business Economics, (2007)

Editing and multiply imputing German establishment panel data to estimate stochastic production frontier models published in: Zeitschrift für ArbeitsmarktForschung 37 (2004),

\section{S. 306-318}

Collective contracts, wages and wage dispersion in a multilevel model

published as: Wage settlements and wage setting : results from a multi-level model. In: Applied Economics, Vol. 37, No. 20 (2005), S. 2297-2306

How collective contracts and works councils reduce the gender wage gap

Local economic structure and industry development in Germany, 1993-2001

How fast do newly founded firms mature? : empirical analyses on job quality in start-ups published in: Michael Fritsch, Jürgen Schmude (Ed.): Entrepreneurship in the region, New York et al., 2006, S. 95-112 Long-run effects of public sector sponsored training in West Germany

Lohnunterschiede zwischen Frauen und Männern in Branchen, Berufen und Betrieben published in: Zeitschrift für Soziologie 34 (2005), S. 22-39, as: Geschlechtsspezifische Lohnunterschiede in Branchen, Berufen und Betrieben

Analyzing the changing gender wage gap based on multiply imputed right censored wages

The linked employer-employee dataset of the IAB (LIAB) published as: The linked employer-employee dataset created from the IAB establishment panel and the process-produced data of the IAB (LIAB). In: Schmollers Jahrbuch. Zeitschrift für Wirtschafts- und Sozialwissenschaften 125 (2005), S. 327336 (shortened)

Labour market dynamics from a regional perspective : the 
$\underline{8 / 2005} \quad \begin{aligned} & \text { Caliendo, M. } \\ & \text { Hujer, R. } \\ & \text { Thomsen, S. L. } \\ & \underline{9 / 2005} \begin{array}{l}\text { Gerlach, K. } \\ \text { Stephan, G. }\end{array}\end{aligned}$

10/2005 Gerlach, K. Stephan, G.

11/2005 Blien, U. Hirschenauer, $F$.

12/2005 Alda, $\mathrm{H}$. Allaart, $P$. Bellmann, L.

13/2005 Caliendo, M. Hujer, R. Thomsen, S. L.

14/2005 Lechner, M. Miquel, R. Wunsch, C.

15/2005 Jensen, U. Rässler, S.

16/2005 Schnabel, C. Zagelmeyer, S. Kohaut, S.

$17 / 2005$ Koch, S. Stephan, G. Walwei, $U$.

18/2005 Alda, $\mathrm{H}$. Bellmann, L. Gartner, $\mathrm{H}$.

19/2005 Eichhorst, W. Konle-Seidl, R.

20/2005 Gerlach, K. Stephan, G.

21/2005 Fitzenberger, B. Speckesser, S.

22/2005 Ludsteck, J. Jacobebbinghaus, $P$.

$\underline{1 / 2006}$

Gerlach, K.

Levine, D.

Stephan, G.

Struck, O.

2/2006 Ludsteck, J.

3/2006 Gaggermeier, C.

4/2006 Binder, J. Schwengler, B.

5/2006 Brixy, U. Grotz, R.
Identifying effect heterogeneity to improve the efficiency of job creation schemes in Germany

Wage distributions by wage-setting regime published as: Bargaining regimes and wage dispersion. In: Jahrbücher für Nationalökonomie und Statistik, Bd. 226, H. 6 $\underline{(2006)}$

Individual tenure and collective contracts

Formula allocation : the regional allocation of budgetary funds for measures of active labour market policy in Germany

Churning and institutions : Dutch and German establishments compared with micro-level data

Individual employment effects of job creation schemes in Germany with respect to sectoral heterogeneity

The curse and blessing of training the unemployed in a changing economy : the case of East Germany after unification

$6 / 05$

Where have all the data gone? : stochastic production frontiers with multiply imputed German establishment data published in: Zeitschrift für ArbeitsmarktForschung, Jg. 39, H. 2, 2006, S. 277-295

Collective bargaining structure and its determinants : an empirical analysis with British and German establishment data published in: European Journal of Industrial Relations, Vol. 12 , No. 2. S. $165-188$

Workfare: Möglichkeiten und Grenzen

published in: Zeitschrift für ArbeitsmarktForschung 38 (2005), S. 419-440

Wage structure and labour mobility in the West German private sector 1993-2000

The interaction of labor market regulation and labor market policies in welfare state reform

Tarifverträge und betriebliche Entlohnungsstrukturen published in: C. Clemens, M. Heinemann \& S. Soretz (Hg.): Auf allen Märkten zu Hause, Marburg 2006, S. 123-143

Employment effects of the provision of specific professional skills and techniques in Germany

Strike activity and centralisation in wage setting

The acceptability of layoffs and pay cuts : comparing North America with Germany

Employment effects

Pension and children : Pareto improvement with heterogeneous preferences

Korrekturverfahren zur Berechnung der Einkommen über der Beitragsbemessungsgrenze

Regional patterns and determinants of new firm formation and survival in western Germany 


\section{6/2006 Blien, U. Sanner, $\mathrm{H}$. \\ 7/2006 Stephan, G. Rässler, S. Schewe, $\mathrm{T}$.}

8/2006 Gash, V. Mertens, A. Romeu Gordo, L.

9/2006 Romeu Gordo, L.

$\underline{10 / 2006}$ Jahn, E. J. Wagner, $T$.

11/2006 Jensen, U. Gartner, $\mathrm{H}$. Rässler, S.

12/2006 Meyer, B. Lutz, C. Schnur, $P$. Zika, G.

13/2006 Beblo, M. Bender, S. Wolf, E.

14/2006 Niebuhr, A.

15/2006 Kiesl, H. Rässler, S.

16/2006 Hujer, R. Zeiss, C.

17/2006 Fitzenberger, B. Osikominu, A. Völter, R.

18/2006 Antoni, M. Jahn, E. J.

19/2006 Fuchs, J. Söhnlein, D.

20/2006 Lechner, M. Wunsch, C.

21/2006 Kruppe, T.

22/2006 Feil, M. Klinger, S. Zika, G.

23/2006 Blien, U. Phan, t. H. V.

24/2006 Lutz, R.

25/2006 Jirjahn, U. Pfeifer, C. Tsertsvadze, G.

26/2006 Rudolph, H.
Structural change and regional employment dynamics

$4 / 06$

Wirkungsanalyse in der Bundesagentur für Arbeit : Konzepti-

$4 / 06$ on, Datenbasis und ausgewählte Befunde published as: Das TrEffeR-Projekt der Bundesagentur für Arbeit : die Wirkung von Maßnahmen aktiver Arbeitsmarktpolitik. In: Zeitschrift für ArbeitsmarktForschung, Jg. 39, H. 3/4 $\underline{(2006)}$

Are fixed-term jobs bad for your health? : a comparison of West-Germany and Spain

Compression of morbidity and the labor supply of older people

Base period, qualifying period and the equilibrium rate of unemployment

Measuring overeducation with earnings frontiers and multiply imputed censored income data

National economic policy simulations with global interdependencies : a sensitivity analysis for Germany

$5 / 06$

$6 / 06$

$6 / 06$

$7 / 06$

The wage effects of entering motherhood : a within-firm matching approach

$8 / 06$

Migration and innovation : does cultural diversity matter for regional $R \& D$ activity?

How valid can data fusion be?

$8 / 06$

$8 / 06$

The effects of job creation schemes on the unemployment

$8 / 06$ duration in East Germany

Get training or wait? : long-run employment effects of training programs for the unemployed in West Germany

Do changes in regulation affect employment duration in temporary work agencies?

Effekte alternativer Annahmen auf die prognostizierte Erwerbsbevölkerung

Active labour market policy in East Germany : waiting for the economy to take off

Die Förderung beruflicher Weiterbildung : eine mikroökonometrische Evaluation der Ergänzung durch das ESF-BAProgramm

Sozialabgaben und Beschäftigung : Simulationen mit drei makroökonomischen Modellen

$10 / 06$

A pilot study on the Vietnamese labour market and its social and economic context

Was spricht eigentlich gegen eine private Arbeitslosenversicherung?

Mikroökonomische Beschäftigungseffekte des Hamburger Modells zur Beschäftigungsförderung SGB II : Erfolgs- und Effizienzkriterien als Leistungsanreiz? 
$\underline{27 / 2006}$ Wolff, J.

28/2006 Blien, U.

Kirchhof, K.

Ludewig, $\mathrm{O}$.

29/2006 Blien, U.

Hirschenauer, F. Phan, t. H. V.

30/2006 Krug, G.

1/2007 Moritz, M.

Gröger, M.

2/2007 Hampel, K.

Kunz, M.

Schanne, N.

Wapler, R.

Weyh, A.

3/2007 Eckey, H.- F Schwengler, B. Türck, M.

4/2007 Kristen, C. Granato, N.
How does experience and job mobility determine wage gain

$12 / 06$

in a transition and a non-transition economy? : the case of east and west Germany

Agglomeration effects on labour demand

$12 / 06$

Model-based classification of regional labour markets : for

$12 / 06$ purposes of labour market policy

Kombilohn und Reziprozität in Beschäftigungsverhältnissen : eine Analyse im Rahmen des Matching-Ansatzes

The German-Czech border region after the fall of the Iron

Curtain: Effects on the labour market : an empirical study using the IAB Employment Sample (IABS)

Regional employment forecasts with spatial interdependencies

Vergleich von deutschen Arbeitsmarktregionen

The educational attainment of the second generation in Germany : social origins and ethnic inequality

Stand: 23.1 .2007 


\section{IABDiscussionPaper}

No. 5 / 2007

\section{Editorial address}

Institut für Arbeitsmarkt- und Berufsforschung der Bundesagentur für Arbeit

Weddigenstr. 20-22

D-90478 Nürnberg

\section{Editorial staff}

Regina Stoll, Jutta Palm-Nowak

\section{Technical completion}

Jutta Sebald
All rights reserved

Reproduction and distribution in any form, also in parts, requires the permission of IAB Nürnberg

Download of this DiscussionPaper:

http://doku.iab.de/discussionpapers/2007/dp0507.pdf

\section{Website}

http://www.iab.de

For further inquiries contact the author:

Corinna Kleinert, Tel. 0911/179-3075,

or e-mail: corinna.kleinert@iab.de 